\title{
大型走滑断层一一碰撞后陆内变形的 重要形式*
}

\author{
钟大㐘 P. Tapponnier** 吴海威 张连生 秋少丞 钟嘉䊅 \\ 刘小汉 U. Schaerer** R. Lacassin ${ }^{* *}$ P. Leloup ${ }^{* *}$ \\ （中国科学院地质研究所,北京; **法国科研中心地球物理研究所）
}

\section{关镜词陆内变形、大型走滑、红河一哀安山断裂}

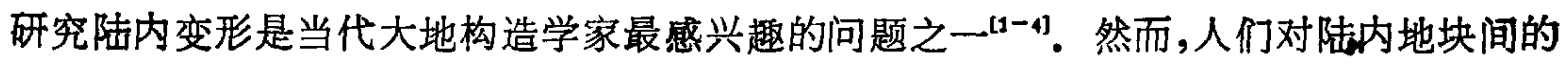
大规模滑移和转动而引起的岩石变形, 变质和岩浆活动研究得非常不够。本文以云南西部哀 守山-红河断裂为例, 说明陆内大规模韧性变形带的几何学、运动学, 以及相关的地质演化过 程.

\section{一、哀牢山 - 红河断裂带在滇西构造格架中的地位}

衰安山一红河断裂带通常列为中国南部杨子断块最西的边界断裂15,60 或认为是一条板块㖓 合线 ${ }^{[3}$. Tapponnier 和 Molnar ${ }^{[3]}$ 从模拟实验探讨东亚新生代构造时, 提出红河断裂是大型 走渭断裂. 近年来我们调查后认为, 衰牢山一红河断裂带是一个复杂的构造带, 现在它最明显 的特征是喜山期的大规模斜冲走滑韧性韵切带。

该断裂带由两条主断裂组成（图 1), 东侧为红河断裂,西侧为衰审山断裂,前者大致沿红 河延展, 后者沿哀暒山分水岭以西展布. 两断裂之间是变形较弱的一套角闪岩相的深变质岩, 即一般所称的哀牢山群和苍山群。这套变质岩已有的同位素年龄为 $839 \pm 73.9 \mathrm{Ma}(\mathrm{Rb} / \mathrm{Sr})$, 代 表了变质年龄,看来它们是扬子断块的深部变质基底由于逆冲向上出露于地表的岩片.

哀审山断裂以西,出露一套绿片岩相的粉础质、泥质的沉积岩和中酸性火山岩, 其时代推 测属晚古生代. 在双沟一带的浅变质岩带内, 出露有蛇绿岩套, 它们形成的构造环境和整个衰 暒山构造带大地构造演化, 我们将在另文中讨论.

\section{二、哀安山-红河斜冲走滑断裂带的变形特征}

1. 面、线理 哀暒山一红河断裂带由二条主断裂组成。萁切带的面理无论沿走向上或 同一剖面不同部位是变化的. 在南段（金平一红河县间）沿红河断裂的构造岩面理的走向为 $310 \sim 320^{\circ}$, 倾向北东, 倾角 $60-70^{\circ}$. 向北至元江一漠沙一戛沙一带, 衰审山与红河断裂逐渐会 聚, 糜棱岩面理走向稳定 $330 \sim 340^{\circ}$, 倾向北东, 倾角 $60 \sim 70^{\circ}$. 到大理苍山一带, 糜棱岩面理 走向亦为 $330^{\circ}$, 倾向北东, 但面理倾角有变化, 靠近湒海一侧, 以陡侧为主 $\left(70 \sim 80^{\circ}\right)$, 而下关

本文 1988 年7月21日收到。

*国家自然科学基金资助项目。本合作项目还得到中国科学院和法国科研中心的资助. 


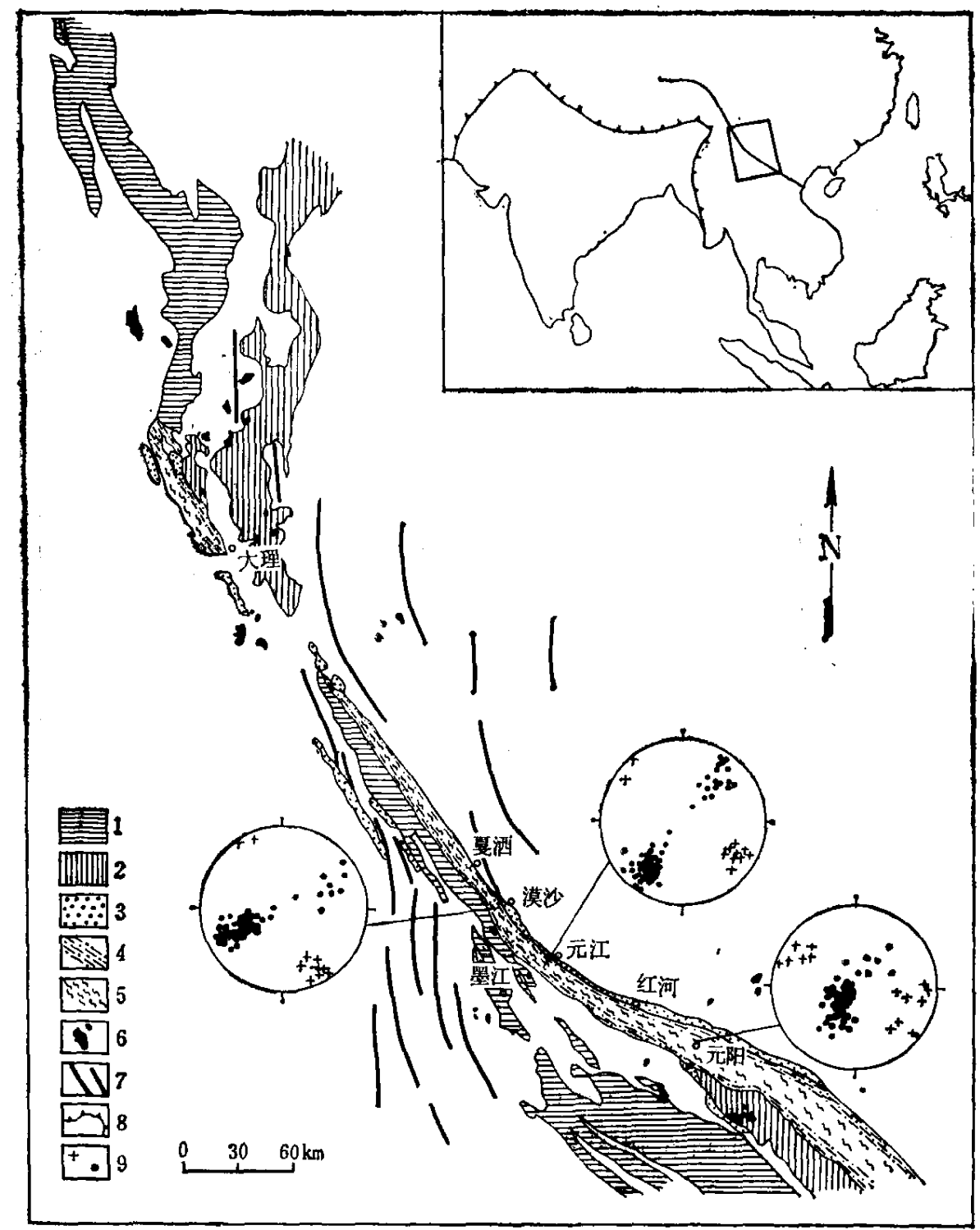

图 1 红河-哀审山断裂带构造略图

1.加里东-海西构造带；2.杨子陆块边缘沉积带 (Pz-T)；3. 新第三纪沉积盆地；4.前寒武纪片麻 岩-结晶片岩带；5.第三纪富喊花岗岩带；6.糜稜岩带；7.中、新代红层中的喜马拉雅期褶皱轴迹： 8.板块琏合线(右上角插图)；9. 面理产状极点投影，十线理产状投影.

注意：扬子陆块古生代-三叠纪沉积带在断裂两侧呈左旋错位约 $320 \mathrm{~km}$

至泳㵋公路剖面上,则以缓倾斜面理为主,其倾角在 $30^{\circ}$ 左右. 这可能反怏了不同时期变形的 产物,也可能是应变的非均匀性所造成的.

沿哀审山一红河断裂带, 分别发育典型的糜棱岩, 在各个地段的宽度变化很大, 从 $2 \sim 3 \mathrm{~km}$ 到数百公尺. 这些糜棱岩的一个显著特点是广泛发育线理. 在糜棱岩的 $X Y$ 面上,长石碎班 组成的拉伸线理的走向比较稳定 $150 \sim 160^{\circ}$, 倾状角一般为 $10^{\circ}$, 局部可见 $20 \sim 30^{\circ}$. 另一种 线理是糜棱岩或糜棱岩化的片麻岩的折叠层组成的鞘褶曲的线理和杆状线理, 它们的走向和 倾伏方向都和拉伸线理平行. 在缓倾斜面理的糜棱岩上, 线理走向为 $100 \sim 105^{\circ}$, 倾伏角 $\approx 10^{\circ}$.

2. 显微构造糜棱岩的 $\mathrm{YZ}$ 和 $\mathrm{XZ}$ 切片中,动态重结晶的石英、黑云母基触成的纹 
带构成平行于糜棱面理，而石英一长石质的碎斑呈大小不一的菱形、梢圆形集合体,组成微布 丁构造、旋转构造、斜列构造，有的还见到典型的 S-C 构造. 大量统计表明，尊切指向是左旋 的.

在露头尺度范围内, 强变形的长英质片麻岩中的暗色角闪质岩或宽的角闪斜长质岩中的 浅色长英质薄层, 在 $X Z$ 面上,它们常呈细颈化成藕节构造、布丁构造、布丁斜列和转动构造、 $S-C$ 构造等, 它们也都显示左旋剪切位移的特点.

㓞性剪切带的另一特点是在 $Y Z 、 X Z$ 面上,见到强烈缩短现象. 例如,在糜棱岩 $Y Z$ 面 上的长石碎斑亦显示强烈压扁变形, 长英质脉和角闪质层呈布丁化和透镜化, 具左琁错列特 点, 这说明沿剪切带的的滑移, 不单纯是简单剪切, 而是一种挤压剪切, 沿 $X$ 轴有剪切拉伸变 形,在 $Y, Z$ 轴上也有很大的剪切挤压缩短.

3. 滑距野外测量上述角闪质岩布丁的剪切位移或长英质条带剪切应变量, 一般 $r=$ 1:15 1:20 之间,最大的 $r$ 为 1:50. 如以元江一戛沙区段内,剪切带的最大宽度为 $5 \mathrm{~km}$. 按剪 切位移量公式计算,水平剪切距约为 $100 \sim 250 \mathrm{~km}$. 我们根据哀审山一红河断裂带两侧对应的 构造一一地层体的左旋相对滑移约 $320 \mathrm{~km}^{*}$ (图 1). 号据古地磁研究 ${ }^{[8]}$ 在 $\mathrm{J}_{2}$ 以来,印支地块相 对华南地块经历了约 $10^{\circ}$ 的顺时针转动. 粗略计算, 沿哀审山一红河断裂带的水平位移距大约 是 $120 \mathrm{~km}$.

4. 构造形成深度和时代根据糜棱岩中斜长石的重结晶现象, 同构造期的铁铝炻榄石 的出现, 在竟切带内见到较为普遍的部分融熔现象 ${ }^{[9]}$, 表明该剪切带的形成时的温度至少在 $550 \sim 650^{\circ}$ 以上, 而大致在 $20 \mathrm{~km}$ 或以下的地壳层内形成的.

本区古新世与始新世之间的区域不整合，反映了陆内碰撞变形的下限。这一时限大抵相 当于印度板块沿印度河一雅鲁藏布江㖓合带与欧亚板块碰撞的时间. 从沿哀牢山走滑运动影 响到附近的中生代红层,表明走滑发生在白严纪之后，根据哀牢山一红河断裂带糜棱岩（含剪 切带中的斜长花岗岩、片麻岩和斜长角闪片麻岩的残块)的黑云母、角闪石、白云母的 $\mathrm{Ar} / \mathrm{K}$ 和 $\mathrm{Ar}^{40} / \mathrm{Ar}^{39}$ 的年龄值均落在 $30 \sim 20 \mathrm{Ma}$ 的范围内，暗示大规模的剪切活动发生在渐新世和中新 世之间. 沿红河断裂东侧的一系列串珠状新第三纪盆地, 底部有大量的砾岩层属磨拉式山前 盆地堆积,指示了新第三纪以来(约 $20 \mathrm{Ma}$ ))哀牢山才开始迅速抬升. 因此, 可以把大规模剪切 滑移的时间上限定在新老第三纪之间。这也和整个滇西地区的新生代期间另一个较为普遍的 不整合时限是吻合的.

\section{三、讨论和结论}

沿哀安山一红河断裂发生的大规模左行剪切滑移是和印度板块在晚白正世一古新世（78 $\mathrm{Ma}$ ) 以来, 开始向北漂移, 由南而北的俯冲, 洋壳消减, 大陆碰撞造山事件的一个组成部分. 其 碰撞的时间大约在古新世-始新世 $(50 \mathrm{Ma} \sim 40 \mathrm{Ma})$, 属冈底斯钻碱性岩浆带的拉萨以北花岗岩

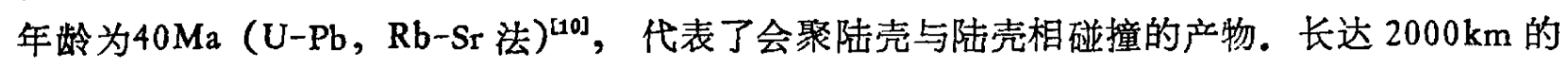
哀牢山一金沙江带富碱花岗侵入活动都出现在 $49 \sim 33 \mathrm{Ma}^{[11]}$. 显然是已拼合的陆壳间再次消减 和相互滑动的产物. 而大规模的左行走滑发生在稍后的 $30 \sim 20 \mathrm{Ma}$ 期间. 这一时限又和哀牢 山-红河断裂南东延伸至海域部分一一南海中央海盆的扩张时间吻合的(南海中央海盆海底的

* 钟大糔、孙埙章,全国推覆构造会议论文摘要汇编, 1985 . 
地磁条带为 32 17Ma). 古地磁资料还证明, 自中侏罗世以来, 印支地块相对于华南地块发 生了右旋转动 ${ }^{[8]}$. 当这种转动受到其他相邻地块限制时, 这就引起华南地块向东推移, 沿哀牢 山-红河断裂的应力状态将由压剪切, 转变为张剪切, 这形成了沿红河的新第三纪断陷盆地, 其 中最大的河内盆地, 新第三系厚度达 $2000 \sim 6000 \mathrm{~m}$, 相应地红河断裂的滑向此时发生反转, 变 形右旋,表现在沿红河的晚第三纪断陷盆地的沉积的年代由南而北逐渐变新, 南海中央海盆停 止扩张,代之南海海盆的整体下沉.

在新生代时期,青藏高原及其周缘的不同地区处于挤压,剪切和拉张状态, 是与 Tapponnier 和 Molnar ${ }^{[3]}$ 提出的刚性的印度板块压人塑性欧亚板块模型的分析是一样的. 但我们认 为,不能把欧亚板块当一个塑性层处理. 在第三纪时期, 沿衰牢山一红河断裂带发生大规模的 陆内走滑, 与先前存在一个大的构造边界有很大的关系. 折射地震测深剖面初步结果表明, 衰 审山一红河断裂带的两侧,杨子地块和滇西地块的地壳的结构和各层厚度都有明显的不同. 当 印度板块向北推进时, 衰审山-红河边界带就成为应力-应变集中的边界. 此外,陆内大尺度尊 切应变还需有高热水边界, 才能使岩石的固态流变速度大大增加. 从剪切带中广泛发育的部 分熔融现象, 推测先存的构造边界也是高温热水聚集和渗流的场所. 当岩块大尺度滑移时, 它 们起了“润滑”作用。

致谢: 本文撰写过程中, 常承法教授、林金录博士提出宝贵意见; 李风仙工程师清绘了图稿, 在此一并致 谢.

\section{参考文献}

[1] Allegre, C. J. et al., Nature, 307(1984), 17-22.

[2] Mattauer, M., C. R. Acad. Sci., Paris, 296(1985), 2: 481-486.

[ 3 ] Tapponnier, P. and Molnar,P., Nature, 264(1977), 319-324.

[4] Tapponnier, P. et al., Geological Society Special Pullication, 1986, 19: 115-157.

[5] 张文佑等,中国及邻区海陆大地构造图,科学出版社,1983.

[6]互纪舜等,中国大地构造及其演化(1:400 万)，科学出版社, 1980 .

[7] 段新华等,地质学报，1981，4：55.

[8] 林金录,地裳地质, 10(1988), 3: 1-11.

[9] 楼少丞,地质科学, $1988,4: 347-356$.

[10] Xu Rong-Hua, et al., J. of Geology, 93(1985), 41-57.

[11] 张玉泉等,岩石学报, 1987,1: 17-26。 